\title{
ORIGINAL ARTICLE Parental presence within households and the impact of antiretroviral therapy in Khayelitsha, Cape Town
}

\author{
C Jury, BBusSci; N Nattrass, DPhil \\ AIDS and Society Research Unit, Centre for Social Science Research, University of Cape Town, Cape Town, South Africa
}

Corresponding email: N Nattrass (nicoli.nattrass@gmail.com)

\begin{abstract}
Background. While household support is an important component of effective care and treatment in HIV/AIDS, there are few insights from Southern Africa into how household support arrangements change over time for patients starting antiretroviral therapy (ART).

Objective. We hypothesised that patients initiating ART are more likely to be living with family, especially their mothers, compared with the general population, but that over time these differences disappear.

Methods. A panel survey of ART patients was matched by age, gender and education to a comparison sample drawn from adults in Khayelitsha, Cape Town.

Results. The results show that there is a substantial potential burden of care on the families of patients starting ART, particularly mothers, and that the use of ART appears to reduce this burden over time. But, even after their health is restored, ART patients are significantly less likely to have a resident sexual partner and more likely to be living in single-person households than their counterparts in the general population.
\end{abstract}

S Afr J HIV Med 2013;14(2):70-74. DOI:10.7196/SAJHIVMED.921

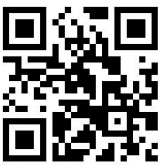

There is evidence that people living with HIV/ AIDS (PLWHA) across sub-Saharan Africa rely on family members, especially parents, for ongoing care and support, particularly with the morbidity of advanced HIV disease. Several studies have shown that terminally ill South African (SA) adults often return to the parental home to access care and support, primarily from their mothers. ${ }^{[1-4]}$ As Haour-Knipe ${ }^{[5]}$ points out, this is to be expected in many settings where extended family serves as the 'primary social safety net'. A Ugandan study found that elderly parents, especially mothers, were the main caregivers for PLWHA ${ }^{[6]}$ and similar dynamics have been reported in Thailand. ${ }^{\left[{ }^{[7]}\right.}$ However, there are few studies exploring whether reliance on family and parental support changes after initiation of antiretroviral therapy (ART).

What sets Southern Africa - and especially SA - apart is the generally lower presence of fathers in households and the importance of 'uterine kin' (mothers, grandmothers and sisters) in providing social stability and care when necessary. ${ }^{[8-10]}$ This is a consequence of SA's history of oscillating migration and apartheid, which separated families geographically, often for long periods of time. But, it is also a consequence of declining rates of marriage, to the point that it is no longer the norm. ${ }^{[11]}$ Hunter argues that the rise of unemployment was the key factor behind this, as only the relatively well-off African men could afford to pay 'ilobolo' (bridewealth) or act as reliable providers for their families. ${ }^{[12-14]}$ Under these circumstances, women become incentivised to form looser connections with men (sometimes several men) and closer bonds with siblings and mothers.

The phenomenon of the 'absent father' has been well documented in SA. ${ }^{[15-17]}$ What this means in terms of the supporting role of fathers, however, is unclear. According to Morrel and Richter, ${ }^{[15]}$ paternal absence implies a lack of fatherly support for children's care. However, other research emphasises how fathers can and often do maintain meaningful contact with children, even when they do not reside in the household ${ }^{[8]}$ and that their role in providing care when they are in the household often goes unreported. ${ }^{[18,19]}$

We investigated aspects of living arrangements for ART patients over time, at the time of ART initiation and subsequently, and compared this with the living arrangements of people of similar age, gender and education in the general population of residents of Khayelitsha, Cape Town.

\section{Methods}

Khayelitsha is a peri-urban settlement comprising about half a million predominantly Xhosa-speaking residents. Almost half of the working-age adults are without jobs and over a quarter of pregnant women are HIV-positive. ${ }^{[2-22]}$ Between 2001 (when the first ART pilot programme was established in Khayelitsha) and 2008, more than 10000 people were successfully initiated on ART with over $93 \%$ retained in care. ${ }^{[23]}$ 
Table 1. Attrition analysis*

\begin{tabular}{|c|c|c|c|c|c|c|}
\hline \multirow[b]{2}{*}{ Characteristics } & \multirow{2}{*}{$\begin{array}{l}\text { Loss to } \\
\text { follow-up }\end{array}$} & \multirow[b]{2}{*}{ In panel } & \multirow{2}{*}{$\begin{array}{l}\text { Univariate probit } \\
\text { coefficient } \\
R^{2}(95 \% \mathrm{CI})\end{array}$} & \multicolumn{3}{|c|}{$\begin{array}{l}\text { Multiple regression probit coefficient } \\
\qquad R^{2}(95 \% \mathrm{CI})\end{array}$} \\
\hline & & & & ART start (wave 0) & ART (wave 2) & Khayelitsha (wave 2) \\
\hline Age (years) & 38 & 33 & $0.04^{\dagger}(0.02-0.07)$ & $0.04^{\ddagger}(0.01-0.07)$ & $0.04^{\ddagger}(0.01-0.07)$ & $0.04^{\ddagger}\left(\begin{array}{lll}0.01 & 0.07\end{array}\right)$ \\
\hline Schooling (years) & 8.5 & 9.7 & $-0.07^{\dagger}(-0.13-0.01)$ & $-0.03(-0.10-0.04)$ & $-0.01(-0.08-0.06)$ & $-0.02(-0.09-0.06)$ \\
\hline Female, \% & 75 & 80 & $-0.17(-0.62-0.28)$ & $-0.01(-0.46-0.49)$ & $-0.02(-0.50-0.47)$ & $-0.06(-0.55-0.45)$ \\
\hline $\begin{array}{l}\text { Worst health ever at } \\
\text { ART start, \% }\end{array}$ & 39 & 40 & $0.03(-0.35-0.42)$ & $-0.08(-0.49-0.31)$ & $-0.01(-0.44-0.42)$ & $-0.04(-0.47-0.40)$ \\
\hline Working, \% & 18 & 37 & $-0.54^{\ddagger}(-0.99-0.09)$ & & $-0.47^{\ddagger}(-0.93-0.00)$ & $-0.40(-0.90-0.11)$ \\
\hline $\begin{array}{l}\text { Disability grant } \\
\text { recipient, \% }\end{array}$ & 83 & 72 & $0.33(-0.13-0.80)$ & & $0.31(-0.20-0.82)$ & $0.241(-0.29-0.77)$ \\
\hline $\begin{array}{l}\text { Per capita } \\
\text { household income } \\
\text { (ZAR) }\end{array}$ & 487 & 630 & $-0.00(-0.00-0.00)$ & & & $-0.00(-0.00-0.00)$ \\
\hline $\begin{array}{l}\text { Mother in } \\
\text { household, \% }\end{array}$ & 19 & 23 & $-0.16(-0.61-0.30)$ & & & $0.16(-0.95-1.27)$ \\
\hline $\begin{array}{l}\text { Father in } \\
\text { household, \% }\end{array}$ & 5 & 5 & $-0.09(-0.94-0.76)$ & & & $0.08(-0.93-1.10)$ \\
\hline $\begin{array}{l}\text { Parent-headed } \\
\text { household, \% }\end{array}$ & 16 & 22 & $-0.21(-0.69-0.26)$ & & & $-0.18(-1.39-1.04)$ \\
\hline $\begin{array}{l}\text { Partner in } \\
\text { household, \% }\end{array}$ & 19 & 32 & $-0.40^{\S}(-0.84-0.04)$ & & & $-0.31(-1.80-0.17)$ \\
\hline Pseudo $R^{2}$ & & & & 0.055 & 0.081 & 0.088 \\
\hline$N$ & & & & 242 & 242 & 234 \\
\hline Probability $>$ chi $^{2}$ & & & & 0.018 & 0.007 & 0.064 \\
\hline $\begin{array}{l}\mathrm{CI}=\text { confidence interval. } \\
{ }^{*} \text { Dependent variable: } 1=\text { los } \\
{ }^{+} p<0.001 . \\
{ }^{*} p<0.05 . \\
{ }^{\circ} p<0.1 .\end{array}$ & follow-up; 0 & ull panel stud & & & & \\
\hline
\end{tabular}

In 2004, 242 patients receiving ART in Khayelitsha were recruited into a panel study conducted by the AIDS and Society Research Unit of the University of Cape Town. Respondents were recruited through social networks, clinic support groups and by word of mouth; hence, the sample cannot be regarded as strictly representative. However, as twothirds of the starting ART cohort was recruited into the study, the sample can be regarded as broadly representative of the experience of the early ART patients. ${ }^{[24]}$

The first round of the survey (wave 1) was conducted in 2004 and a second wave in 2006. Retrospective questions were posed to respondents regarding their households and health at the time that they started ART, thereby allowing us to construct a retrospective 'wave 0' (i.e. at the time of ART initiation, when they were sick with AIDS) for all respondents.

The panel study allowed examination of the changes in household characteristics of ART patients over time, but we also needed to know how this compared with households in the general population. We therefore constructed a 'quasi control' dataset drawn from a survey of Khayelitsha residents (which can be regarded as representative of adult African Khayelitsha residents $\left.{ }^{[29]}\right)$, conducted in parallel with the ART panel study. From this dataset we drew a sub-sample of 202 respondents matched (using a probit regression) by age, gender and education to respondents in the ART sample.

Ethics approval for the studies was obtained from the Ethics Committee of the Centre for Social Science Research, in line with the ethics approval process of the University of Cape Town.

\section{Results}

Within the ART panel study, loss to follow-up was $16 \%$ (of the 242 respondents interviewed in 2004, only 202 were present for all subsequent interviews). Older respondents in wave 1 were more likely to be lost to followup (Table 1), but the effect was small (for each additional year of age, the probability of loss to follow-up rose by $4 \%$ ). Those without jobs were more likely to be lost to follow-up (being employed cut the probability of loss to follow-up by one-half), but once controls were implemented for household income and other household characteristics, the effect of being employed became statistically insignificant. Having a resident sexual partner reduced the probability of attrition, but this effect also became statistically insignificant once controls were implemented for other factors. In multivariate analysis, there were no systematic differences in socio-economic and demographic characteristics between those lost to follow-up and those retained in care, other than small differences in age. Furthermore, the explanatory power of the regression models remained low in all specifications.

The matching process resulted in a matched and balanced panel dataset of ART patients and Khayelitsha respondents, with almost identical average age, gender and educational profiles (Table 2). Respondents were asked to rank on a 10-point scale (with 10 being the best health that they had ever experienced) 
their current health status as well as their recollections of their health at the time that they initiated ART, and three and six months later. The mean score for perceived health rose from 2.8 (standard deviation $(\mathrm{SD}) \pm 2.2$ ) at ART initiation to $5.3(\mathrm{SD} \pm 2.0)$ three months later and $7.8(\mathrm{SD} \pm 1.7)$ six months later - an increase in line with improvements in clinical markers (e.g. CD4 cell counts) and qualityof-life indicators found in other studies of the same Khayelitsha cohort. ${ }^{[20,25-28]}$

Given the potential for ART to restore health and independence, we expected the ART rollout to result in changes in household characteristics, especially involving mothers and sisters. Accordingly, we hypothesised that mothers and sisters were more likely to be present in the households of patients initiating ART. We found that maternal presence in the

\section{Table 2. Matched data sets}

\begin{tabular}{lll}
\hline & ART panel & Khayelitsha matched sample \\
\hline Women, \% & 80 & 80 \\
Age (wave 1), years \pm SD & $33.2 \pm 6.5$ & $33.6 \pm 7.4$ \\
Education (wave 1), years \pm SD & $9.7 \pm 2.8$ & $9.9 \pm 2.5$ \\
Total, $N$ & 202 & 202 \\
SD = standard deviation. & &
\end{tabular}

household decreased significantly from 31\% to $19 \%$ between wave 0 (ART initiation) and wave 2 (Table 3 ). Indeed, by wave 2 , there was no significant difference between maternal presence in ART-patient households and those of the matched Khayelitsha residents. The trend was similar and statistically significant also for households with no mother but with a sister present.

An analysis of changes in paternal presence are reported in Table 3. We found that fathers were generally less present than mothers, in both the ART and matched Khayelitsha samples. However, as was the case with maternal presence, fathers were significantly more likely to be present in the household when ART respondents were sick with AIDS, rather than later. Whether fathers were actively playing any caring or supportive role could

Table 3. The presence of mothers, sisters, fathers and parent-headed households

\begin{tabular}{|c|c|c|c|}
\hline & ART start (wave 0) & ART (wave 2) & Khayelitsha (wave 2) \\
\hline Mother present in the household & $62(30.7 \%)$ & $39(19.3 \%)$ & $43(21.3 \%)$ \\
\hline $\begin{array}{l}\text { Testing the statistical significance of the difference } \\
\text { between wave } 0 \text { and wave } 2 \text { of the ART sample }\end{array}$ & \multicolumn{2}{|c|}{$\begin{array}{l}\text { Pearson } \text { chi }^{2}=93.58 ; p=000^{*} \\
\text { Fisher's exact: } 0.000^{*}\end{array}$} & \\
\hline $\begin{array}{l}\text { Testing the statistical significance of the difference } \\
\text { between wave } 2 \text { of the ART and Khayelitsha samples }\end{array}$ & \multicolumn{3}{|c|}{$\begin{array}{l}\text { Pearson } \text { chi }^{2}=0.24 ; p=0.621 \\
\quad \text { Fisher's exact: } 0.711\end{array}$} \\
\hline No mother but at least one sister in the household & $40(19.8 \%)$ & $30(14.9 \%)$ & $26(12.9 \%)$ \\
\hline $\begin{array}{l}\text { Testing the statistical significance of the difference } \\
\text { between wave } 0 \text { and wave } 2 \text { of the ART sample }\end{array}$ & \multicolumn{2}{|c|}{$\begin{array}{l}\text { Pearson } \text { chi }^{2}=48.73 ; p=0.000^{*} ; \\
\text { Fisher's exact: } 0.000^{*}\end{array}$} & \\
\hline $\begin{array}{l}\text { Testing the statistical significance of the difference } \\
\text { between wave } 2 \text { of the ART and Khayelitsha samples }\end{array}$ & \multicolumn{3}{|c|}{$\begin{array}{l}\text { Pearson } \text { chi }^{2}=0.33 ; p=0.565 \\
\quad \text { Fisher's exact: } 0.666\end{array}$} \\
\hline Father present in the household & $15(7.4 \%)$ & $9(4.5 \%)$ & $19(9.4 \%)$ \\
\hline $\begin{array}{l}\text { Testing the statistical significance of the difference } \\
\text { between wave } 0 \text { and wave } 2 \text { of the ART sample }\end{array}$ & \multicolumn{2}{|c|}{$\begin{array}{l}\text { Pearson } \text { chi }^{2}=48.09 ; p=000^{*} \\
\quad \text { Fisher's exact: } 0.000^{*}\end{array}$} & \\
\hline $\begin{array}{l}\text { Testing the statistical significance of the difference } \\
\text { between wave } 2 \text { of the ART and Khayelitsha samples }\end{array}$ & \multicolumn{3}{|c|}{$\begin{array}{l}\text { Pearson } \text { chi }^{2}=3.84 ; p=0.050^{+} \\
\text {Fisher's exact: } 0.076^{+}\end{array}$} \\
\hline Parent-headed household & $60(70.3 \%)$ & $35(17.3 \%)$ & $42(20.8 \%)$ \\
\hline $\begin{array}{l}\text { Testing the statistical significance of the difference } \\
\text { between wave } 0 \text { and wave } 2 \text { of the ART sample }\end{array}$ & \multicolumn{2}{|c|}{$\begin{array}{l}\text { Pearson } \text { chi }^{2}=84.57 ; p=0.000^{*} \\
\text { Fisher's exact: } 0.000^{*}\end{array}$} & \\
\hline $\begin{array}{l}\text { Testing the statistical significance of the difference } \\
\text { between wave } 2 \text { of the ART and Khayelitsha samples }\end{array}$ & \multicolumn{3}{|c|}{$\begin{array}{l}\text { Pearson } \text { chi }^{2}=0.79 ; p=0.375 \\
\text { Fisher's exact: } 0.447\end{array}$} \\
\hline
\end{tabular}

not be ascertained from the data. There was a statistically significant increase between wave 0 and wave 2 in the number of ART respondents who were themselves household heads (Table 4). More than half of the respondents in the ART sample were household heads by wave 2 .

In addition, we examined changes in reported sexual partnerships over time, comparing ART patients with the general population. There was indeed a statistically significant increase in the number of ART patients with resident sexual partners (Table 5), but this remained significantly lower than for the matched Khayelitsha sample.

\section{Discussion}

We employed an innovative methodology to compare trends in a panel study of ART patients in Khayelitsha with a matched sample drawn from the local population. We confirmed the pattern found in the existing literature that people with AIDS rely on kin, especially mothers, for care and support. ${ }^{[2-5,9]}$ A limitation of our study was that we could not ascertain whether it was the patient or the caregiver that moved households. Even so, we were able to establish that ART patients were more likely to be living in parent-headed households when they initiated treatment than 
Table 4. Respondent-headed and single-person households

\begin{tabular}{|c|c|c|c|}
\hline & ART start (wave 0) & ART (wave 2) & Khayelitsha (wave 2) \\
\hline Respondent as head of household & $65(32.2 \%)$ & $110(54.5 \%)$ & $85(42.1 \%)$ \\
\hline $\begin{array}{l}\text { Testing the statistical significance of the difference between wave } \\
0 \text { and wave } 2 \text { of the ART sample }\end{array}$ & \multicolumn{2}{|c|}{$\begin{array}{l}\text { Pearson } \text { chi }^{2}=55.37 ; p=000^{*} \\
\quad \text { Fisher's exact: } 0.000^{*}\end{array}$} & \\
\hline $\begin{array}{l}\text { Testing the statistical significance of the difference between wave } \\
2 \text { of the ART and Khayelitsha samples }\end{array}$ & & \multicolumn{2}{|c|}{$\begin{array}{l}\text { Pearson } \text { chi }^{2}=6.20 ; p=0.013^{\dagger} \\
\quad \text { Fisher's exact: } 0.017^{\dagger}\end{array}$} \\
\hline Single-person households & $8(4 \%)$ & $17(8.4 \%)$ & $7(3.5 \%)$ \\
\hline $\begin{array}{l}\text { Testing the statistical significance of the difference between wave } \\
0 \text { and wave } 2 \text { of the ART sample }\end{array}$ & \multicolumn{2}{|c|}{$\begin{array}{l}\text { Pearson } \text { chi }^{2}=9.14 ; p=0.002^{\dagger} \\
\text { Fisher's exact: } 0.021^{\dagger}\end{array}$} & \\
\hline $\begin{array}{l}\text { Testing the statistical significance of the difference between wave } \\
2 \text { of the ART and Khayelitsha samples }\end{array}$ & & \multicolumn{2}{|c|}{$\begin{array}{l}\text { Pearson } \text { chi }^{2}=4.33 ; p=0.038^{\dagger} \\
\quad \text { Fisher's exact: } 0.056^{\ddagger}\end{array}$} \\
\hline $\begin{array}{l}{ }^{*} p<0.001 . \\
{ }^{t} p<0.05 . \\
{ }^{t} p<0.1 .\end{array}$ & & & \\
\hline
\end{tabular}

Table 5. The presence of sexual partners in households

\begin{tabular}{|c|c|c|c|}
\hline & ART start (wave 0) & ART (wave 2) & Khayelitsha (wave 2) \\
\hline Partner present in the household & $22(10.9 \%)$ & $69(34.2 \%)$ & $94(46.5 \%)$ \\
\hline $\begin{array}{l}\text { Testing the statistical significance of the difference between wave } \\
0 \text { and wave } 2 \text { of the ART sample }\end{array}$ & \multicolumn{3}{|c|}{$\begin{array}{l}\text { Pearson chi }{ }^{2}=12.71 ; p=000^{\star} \\
\text { Fisher's exact: } 0.001^{\dagger}\end{array}$} \\
\hline $\begin{array}{l}\text { Testing the statistical significance of the difference between wave } \\
2 \text { of the ART and Khayelitsha samples }\end{array}$ & \multicolumn{3}{|c|}{$\begin{array}{l}\text { Pearson } \text { chi }^{2}=6.43, p=0.011^{\dagger} \\
\text { Fisher's exact: } 0.015^{\dagger}\end{array}$} \\
\hline $\begin{array}{l}{ }^{*} p<0.001 . \\
{ }^{+} p<0.05 .\end{array}$ & & & \\
\hline
\end{tabular}

they were after their health had been restored by ART. This implies that significant numbers had returned to the parental home to receive care when they were sick with AIDS.

Our study goes beyond the existing literature on the relationship between AIDS and household structure, by showing that ART reverses the burden of care on kin. Our analysis showed that by wave 2 , i.e. when ART patients had been stabilised on treatment, the ART sample and the matched Khayelitsha sample were indistinguishable with regard to the presence of mothers and sisters and parent-headed households. The shift in living arrangements away from parent-headed households and the declining presence of uterine kin is strongly indicative of the effect of ART on restoring health and independence for young adults living with HIV.

Fathers were less present than mothers (consistent with the broader socio-economic literature $\left.{ }^{[11,12-17]}\right)$, but even so, ART patients were more likely to be living in households with a father present when they were sick with AIDS than they were once their health had been restored. It is possible that all or some of these fathers were providing the kind of care and support found in other studies, ${ }^{[8,18,19]}$ but our data do not speak to this issue.

There is some evidence to suggest that HIV stigma, rather than falling as a result of the ART rollout, may well have risen in Cape Town in the early- to mid-2000s. Using data from the Cape Area Panel Study of young adults, Maughan-Brown ${ }^{[31]}$ found that AIDS stigma increased in the African population between 2003 and 2006 and that fear of infection was the key driver. We therefore hypothesised that the presence of sexual partners in the households of ART patients was likely to have increased over time as health was restored, but in the context of ongoing AIDS stigma and fear of infection, ART patients were probably less likely than their counterparts in the general population to be living with a sexual partner. This hypothesis was supported by the data.
These results are consistent with what we know about the potential for ART to restore health and promote greater independence for PLWHA. However, there may also have been push factors at work - notably, some ART patients may have been forced/encouraged to leave by other household members once they were able to take care of themselves. The fact that there were statistically significantly more single-person households in wave 2 (compared with wave 0 of the ART sample, and wave 2 of the Khayelitsha sample) is consistent both with ART patients exercising greater independence and potentially experiencing persistent stigma and subsequent social isolation.

We found that the number of ART patients with sexual partners rose over time, but compared with the matched comparison sample, ART patients were more likely to be living alone and without sexual partners, even after their health had been restored. This is suggestive of the continued existence of stigma against PLWHA. Medical professionals should 
remain alert to the possibility that stigma may be affecting some of their patients, especially those living alone, and that they may be suffering from social marginalisation.

Acknowledgements. We acknowledge Celeste Coetzee and Takwanisa Machemedze for help in drawing the matched and balanced sample.

\section{References}

1. Bachmann M, Booysen F. Economic causes and effects of AIDS in South African households. AIDS 2006;20:1861-1867. [http://dx.doi.org/10.1097/01. aids.0000244205.03382.84]

2. Clark S, Collinson, J, Kahn M, Drullinger K, Tollman S. Returning home to die: Circular labou migration and mortality in South Africa. Scand Public Health 2007;35(69):35-44. [http://dx.doi.org/ 10.1080/14034950701355619]

3. Schatz E. 'Taking care of my own blood': Older women's relationships to their household in rural South Africa. Scand J Public Health 2007;35(69):147-154. [http://dx.doi org/10.1080/14034950701355676]

4. Welaga P, Hosegood V, Weiner R, Hill C, Herbst K, Newell M. Coming home to die? The association between migration and mortality in rural South Africa. BMC Public Health 2009;9(193):1-8. [http:// dx.doi.org/10.1186/1471-2458-9-193]

5. Haour-Knipe M. Families, children, migration and AIDS. AIDS Care 2009;21(S1):43-48. [http://dx.doi. org $/ 10.1080 / 09540120902923071]$

6. Ssengonzi R. The plight of older persons as caregivers to people infected/affected by HIV/AIDS Evidence from Uganda. J Cross-Cult Gerontology 2007;22(4):339-353

7. Knodel J, Van Landingham M. Return migration in the context of parental assistance in the AIDS epidemic: The Thai experience. Soc Sci Med 2003;57(2):327-342. [http://dx.doi.org/10.1016/ S0277-9536(02)00361-1]

8. Denis P, Ntsimane R. Absent fathers: Why do men not feature in stories of families affected by HIV AIDS in KwaZulu-Natal? In: Morrel R, Richter L, eds. Baba: Men and Fatherhood in South Africa. Cape Town: Human Sciences Research Council, 2006:237-249.

9. Harper S, Seekings J. Claims on and Obligations to Kin in Cape Town, South Africa. CSSR Working Paper No. 272. Cape Town: Centre for Social Science Research and University of Cape Town, 2010. http://www.cssr.uct.ac.za/publications/workingpaper/2010/claims-and-obligations-kin-cape-townsouth (accessed 1 April 2013)

10. Preston Whyte E. Families without marriage: A Zulu case study. In: Argyle J, Preston Whyte E, eds. Social System and Tradition in Southern Africa. Cape Town, Oxford University Press, 1978:55-83.

11. Seekings J. Measuring the gendered consequences of AIDS: Householding and poverty in South Africa. In: Klot J, Nguyen V, eds. The Fourth Wave: An Assault on Women. Gender, Culture and HIV in the 21st Century. New York: SSRC and Geneva: UNESCO, 2011:423-443.

12. Hunter M. Fathers without 'amandla': Zulu speaking men and fatherhood. In: Morrel R, Richter L, eds. Baba: Men and Fatherhood in South Africa. Cape Town: Human Sciences Research Council, 2006:99-107.

13. Hunter M. The changing political economy of sex in South Africa: The significance of unemployment and inequalities to the scale of the AIDS pandemic. Soc Sci Med 2007;64:689-700. [http://dx.doi. org/10.1016/j.socscimed.2006.09.015]

14. Hunter M. Love in the Time of AIDS. Inequality, Gender and Rights in South Africa. Bloomington: Indiana University Press, 2010.

15. Morrel R, Richter L. Baba: Men and Fatherhood in South Africa. Cape Town: Human Sciences Research Council, 2006:1-12.

16. Hosegood V, Mcgrath N, Bland R, Newell, M. Fathers and the Living Arrangements, Mobility and Survival of Young Children in Rural South Africa. XXVI IUSSP International Population Conference, Marrakech, Morocco. 27 September - 2 October 2009. http://iussp2009.princeton.edu/papers/91007 (accessed 1 April 2013).

17. Bray R, Gooskens I, Kahn L, Moses S, Seekings J. Growing Up in the New South Africa: Childhood and Adolescence in Post-apartheid Cape Town. Cape Town: Human Sciences Research Council Press, 2010

18. Hosegood V, Madhavan S. Data availability on men's involvement in families in sub-Saharan Africa to inform family-centred programmes for children affected by HIV and AIDS. J Int AIDS Soc 2010;13(S2/S5):S2-S5. [http://dx.doi. org/10.1186/1758-2652-13-S2-S5

19. Montgomery C, Hosegood V, Busza J, Timaeus I. Men's involvement in the South African family: Engendering change in the AIDS era. Soc Sci Med 2006;62(10):2411-2419.

20. Boulle A, Van Cutsem G, Hilderbrand K, et al. Seven-year experience of a primary care antiretroviral treatment programme in Khayelitsha, South Africa. AIDS 2010;24(4):563-572. [http:// dx.doi.org/10.1097/QAD.0b013e328333bfb7]

21. Hodes R, Naimak T. Piloting ART in South Africa: The role of partnerships in the Western Cape's provincial roll-out. African Journal of AIDS Research 2011;10(4):415-425

22. Médecins Sans Frontières, Western Cape Province Department of Health, City of Cape Town Health, et al. Khayelitsha 2001 - 2011: Activity Report 2001-2011: Ten Years of HIV/TB Care at Primary Health Care Level; 2011. http://www.msf.org.za/ publication/khayelitsha-activity-report-2001-2011 10-years-hivtb-care-primary-health-care-level (accessed 1 April 2013).

23. Médecins Sans Frontières, Western Cape Province Department of Health, City of Cape Town Department of Health \& University of Cape Town, Infectious Disease Epidemiology Unit Comprehensive TB/HIV Services at Primary Health Care Level: Khayelitsha Annual Activity Report 2007 - 20008; 2008. http://www.msf.org.za/publication/ comprehensive-tbhiv-services-primary-health-carelevel (accessed 1 April 2013).

24. Venkataramani S, Maughan-Brown B, Nattrass N, Ruger J. Social Grants, Welfare, and the Incentive to Trade-off Health for Income among Individuals on ART in South Africa. AIDS Behav 2009; 14:1393 1400. [http://dx.doi.org/10.1007/s10461-009-9642-y]

25. Hughes J, Jelsma J, Maclean E, Darder M, Tinise X. The Health-related quality of life of people living with HIV/AIDS. Disabil Rehabil 2004; 26(6), 371-6. http://dx.doi.org/10.1080/09638280410001662932]

26. Coetzee $\mathrm{C}$. The impact of highly active antiretroviral treatment on employment in Khayelitsha. S Afr Journal Econ 2008; 71(1): 75-85. [http://dx.doi. org/10.1111/j.1813-6982.2008.00166.x]

27. Coetzee C, Nattrass N. Living on AIDS Treatment: A Socio-Economic Profile of Africans Receiving Antiretroviral Therapy in Khayelitsha, Cape Town, CSSR Working Paper No.71. Cape Town: Centre for Social Science Research, University of Cape Town.; 2004. http://www.cssr.uct.ac.za/publications/ working-paper/2004/living-aids-treatment-socioeconomic-profile (accessed 1 April 2013).

28. Rosen S, Larson B, Brennan A, Long L, Fox M Mongwenyana C, Ketlhapile M, Sanne I. Economic outcomes for patients receiving antiretroviral therapy for HIV/AIDS in South Africa are sustained through three years on treatment. PLoS One 2010; 5(9), e12731. [http://dx.doi.org/10.1371/journal.pone.0012731]

29. Magruder J, Nattrass N. Exploring Attrition Bias: The Case of the Khayelitsha Panel Study (20002004). S Afri J Econ 2006; 74(4): 769-781. [http:// dx.doi.org//10.1111/j.1813-6982.2006.00096.x.

30. Nattrass N. Gender and Access to Antiretrovirals in South Africa. Fem Econ 2008;14(4):19-36. [http:// dx.doi.org/10.1080/13545700802266452]

31. Maughan-Brown B. Stigma rises despite antiretroviral roll-out: A longitudinal analysis in South Africa. Soc Sci Med 2010;70:368-374. [http:// dx.doi.org//10.1016/j.socscimed.2009.09.041] 